\title{
Development of High Strength Geopolymer Concrete using Nano Silica
}

\author{
Nancy T. Hussien, Ahmed M. Ahmed, Mohamed H. Agamy, Gouda M. Ghanim
}

\begin{abstract}
Cement production became responsible of polluting the atmosphere by the emission of greenhouse gases. This issue motivate the researchers to work hard to develop a new cementitious materials used in concrete having much lower foot print in environmental pollution. This paper presents the development of high strength geoploymer concrete using nano silica. Ground granulated blast furnace slag (GGBFS) is used as main cementitious material and silica fume (SF) is used as cement replacement by different ratios. The alkaline activator is used in different temperature and samples cured by different methods. Nano silica then added to the optimum geopolymer concrete sample by ratios 1, 2 and $3 \%$ of the total weight of cementitious materials. Samples tested for mechanical properties. The results showed that using hot activator and oven curing samples gives higher mechanical properties. Also using nano silica up to $2 \%$ increases the compressive strength up to $24 \%$ at age 28 days.
\end{abstract}

Keywords: Hot activators temperature, normal activators temperature, oven curing and ambient temperature curing.

\section{INTRODUCTION}

Pollution in cement production is a major environmental issue throughout the world. Geopolymer concrete is an alternate cement as well as environment-friendly material in construction field [1]. Also, it has been reported that Global warming causes by the production of ordinary Portland cement through the emission of greenhouse gases looks carbon dioxide (CO2) into the atmosphere contributes about $65 \%$ of the global warming. So cement production became responsible of this environmental issue. As a solution for this issue an alternative binder is used instead of portland cement. This solution is geopolymer concrete. Geopolymer concrete uses byproduct materials such as fly ash, silica fume, ground granulated blast furnace slag, rice husk and metakaolin asa binder [2]. GGBFS is one of these byproduct materials.

Revised Manuscript Received on December 05, 2020.

* Correspondence Author

Nancy T. Hussien*, Teaching Assistant - Faculty of Engineering Egyptian Russian University, Cairo, Egypt. engnancytarekhussien@yahoo.com

Ahmed M. Ahmed, Assistant professor, Department of Civil and Infrastructure Engineering and Management, Faculty of Engineering and Applied Sciences, Nile University, Sheikh Zayed city, Giza, Egypt and Assistant Professor, Department of Civil Engineering, Faculty of Engineering at Mataria, Helwan University, Cairo, Egypt.amabdelkhalik@gmail.com

Mohamed H. Agamy, Associate professorDepartment of Civil Engineering, Faculty of Engineering at Mataria, Helwan University, Cairo, Egypt. eng_helmy81@yahoo.com

Gouda M. Ghanem, Professor of properties of material - Department of Civil Engineering, Faculty of Engineering at Mataria, Helwan University, Cairo, Egyptand Dean of El-Shorouk Academy for Engineering, Cairo, Egypt. Dgoudaoffice2015@gmail.com

(C) The Authors. Published by Blue Eyes Intelligence Engineering and Sciences Publication (BEIESP). This is an open access article under the CC BY-NC-ND license (http://creativecommons.org/licenses/by-nc-nd/4.0/)
The main components of GGBFS are $\mathrm{CaO}(30-50) \%$, SiO2 (28-38)\%, Al2O3 (8-24)\% and MgO (1-18)\% according to American code [3]. Many researches had done either by partially or completely eliminating OPC and uses thesebyproduct materials instead of it. One of these researches isstudying the development of high strength geopolymer concrete. A mixture of fly ash \& ground granulated blast furnace slag (GGBFS ) were used in geopolymer concrete and the results compared with conventional concrete. The results showed that the geopolymer concrete is more durable than conventional concrete [1]. Addition of alccofine "micro ground granulated blast furnace slag" as a replacement for geopolymer cement improves the mechanical properties [6]. Also it was reported that, specimens made by using a mixture of GGBFS \& silica fume gives higher compressive strength than specimens made using GGBFS, silica fume \& fly ash [7].The optimum silica fume replacement percentage for obtaining maximum compressive strength in conventional concrete is up to $10 \%$ but after this ratio the compressive strength began to reduce [8]. Recently nano technology is being used or considered for use in many applications and it has received increasing attention in building materials. There is a limited knowledge about the mechanism by which NS affects the flow properties, setting times, consistency, workability, rheological, micro structural, mechanical properties etc. of cementitious mixes. A contribution to the development of building materials comprises adding synthetic silica to concrete and cement mortars, whereby the resulting product displays improved aging properties with regard to strength gain, sulphate attack and alkali silica reaction. Due to the high specific surface area for nano material sized colloidal nano silica (CNS) particles, they contribute a highly reactive siliceous material. However, it has not been established whether the more rapid hydration of cement in the presence of NS is due to its chemical reactivity upon dissolution (Pozzolanic activity) or to a considerable surface activity[9].The addition of nano silica in the concrete mixture behaves not only as a filler to improve the microstructure, but also as an activator to promote pozzolanic reaction that resulting in the enhancement of the durability and mechanical properties of the mix [10,11]. Also, it has been reported that the maximum increase in strength was in 5\% nano silica replacement. Workability of cement mortar decreased by increasing the amount of nano silica [12].

\section{EXPERIMENTAL PROGRAM}

With the objective of developing a technology to produce non-ordinary Portland cement concrete. The following principles were used:

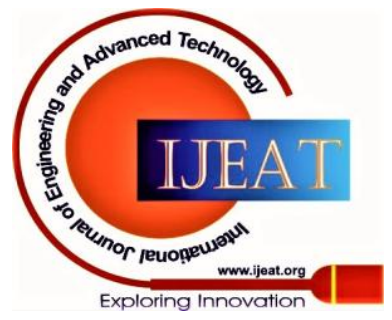




\section{Development of High Strength Geopolymer Concrete using Nano Silica}

- Eliminating OPC completely and use geopolymer binder (GGBFS and SF ) instead of it.

- Activatethe geopolymer cement with a combination of $\mathrm{NaOH}$ and $\mathrm{Na} 2 \mathrm{SiO} 3$ with ratio $1: 2.5$.

- Use coarse aggregate of size $10 \mathrm{~mm}$ and down.

- To improve the workability of fresh concrete Super plasticizer type "G" (sikament R2004)

- Nano silica added in different percentage to improve mechanical properties

- Samples cured in ambient temperature and in oven at temperature $75^{\circ} \mathrm{C}$.

\section{A. Material used}

GGBFS used in this experimental work is water-cooled slag obtained from Ezz flat steel. Silica fume used in this experimental work as cement replacement was obtained from Sika Company.Nano silica used in this experimental work is a white powder brought from National Center for Building and Housing Research.Their chemical composition is given in table-I.

Table-I: Chemical composition of GGBFS, SF and Nano silica

\begin{tabular}{|c|c|c|c|}
\hline Element & GGBFS & SF & NS \\
\hline $\mathrm{CaO} \%$ by mass & 37.1 & 0.21 & 0.14 \\
\hline $\mathrm{Al2O} \%$ by mass & 7.5 & 1.03 & 0.15 \\
\hline $\mathrm{SiO} 2 \%$ by mass & 18.5 & 96.89 & 99.16 \\
\hline $\mathrm{Fe} 2 \mathrm{O} 3 \%$ by mass & 27.9 & 0.56 & 0.05 \\
\hline $\mathrm{MgO} \%$ by mass & 5.24 & 0.15 & 0.12 \\
\hline $\mathrm{MnO} \%$ by mass & 1.37 & - & - \\
\hline $\mathrm{Na} 2 \mathrm{O} \%$ by mass & 1.06 & 0.17 & 0.3 \\
\hline $\mathrm{P} 2 \mathrm{O} 5 \%$ by mass & 0.635 & - & 0.01 \\
\hline
\end{tabular}

Alkali activator consists of sodium hydroxide pellets ( $\mathrm{NaOH}$ with $99 \%$ purity) and sodium silicates solution consists of 0.45 solids $\left(\mathrm{Na}_{2} \mathrm{O}+\mathrm{SiO}_{2}\right)$ and 0.55 of water. The ratio between $\mathrm{SiO}_{2}: \mathrm{Na}_{2} \mathrm{O}$ is approximately 2.5 by mass. Specific gravity of used sodium silicates solution is 1.6 from manufacturer data sheet. To improve the workability of fresh concrete Super plasticizer type "G" (sikament R2004) brought from sika company was used in this investigation. The coarse aggregate used in this experimental work was locally available in Egypt of size $10 \mathrm{~mm}$ and down. Fine aggregate of fineness modulus 2.89 and specific gravity 2.56 is used.

\section{B. Prepairation of Alkaline solution}

Sodium hydroxide pellets is dissolved in clean tap water to make a solution with required concentration (14 mole). Since the molecular weight of sodium hydroxide is 40 , in order to prepare a solution of 14 molar concentration $(14 \mathrm{x} 40)$ 560 gram of sodium hydroxide pellets is dissolved in 1litter of water. Alkaline solution used by two methods with different temperatures:

- The first method, the alkaline activator mixture was prepared a day before mixing because the reaction of sodium hydroxide liberates heat so sodium hydroxide is stand for 24 hours in order to cool down after that it mixed with sodium silicates in ratio of $1: 2.5$ ( $\mathrm{NaOH}: \mathrm{Na}_{2} \mathrm{SiO}_{3}$ ) and the alkali mixture were mixed together until the solution became homogenous. It's called normal activator.

- The second method, sodium hydroxide solution stands for 3 hours then mixed with sodium silicates and used. So in this method the activator temperature is around 50 ${ }^{\circ} \mathrm{C}$. It's called hot activator.

\section{Preparation of $\mathrm{mix}$}

Several trials were performed before arriving at the final mixes.The current experimental program deals with six different Geopolymer concrete mixes to study the effect of using local GGBFS with and without SF to produce geopolymer concrete with different GGBFS \& SF content. The GGBFS replacement by SF by ratios $(0,10,20,30,40$ \& 50) \%.Then the optimum sample is defined by its method of curing and developed by adding nano silica in ratios 1,2 $\& 3 \%$ of the total weight of cementitious materials. All trial mixes has the same Alkali activator/binder ratio but further water was added if needed for workability and the same cement content. Molarity of $\mathrm{NaOH}$ for all trial mixes is 14M. The ratio between $\mathrm{Na}_{2} \mathrm{SiO}_{3}$ : $\mathrm{NaOH}$ is also constant and equal 2.5. Mixing proportions of geopolymer concrete is shown in table-II.

Table -II: Mixing proportions of geopolymer concrete

\begin{tabular}{|c|c|c|c|c|c|c|c|c|c|}
\hline & $\begin{array}{c}\text { Mix } \\
\text { No. }\end{array}$ & $\begin{array}{c}\text { Sand } \\
\mathrm{Kg} / \mathrm{m}^{3}\end{array}$ & $\begin{array}{c}\text { Dolomite } \\
\mathrm{Kg} / \mathrm{m}^{3}\end{array}$ & $\begin{array}{c}\text { Silica } \\
\text { fume } \\
\mathrm{Kg} / \mathrm{m}^{3}\end{array}$ & $\begin{array}{c}\mathrm{GGBFS} \\
\mathrm{Kg} / \mathrm{m}^{3}\end{array}$ & $\begin{array}{c}\mathrm{Nano} \\
\text { silica }\end{array}$ & $\begin{array}{c}\mathrm{NaOH} \\
\mathrm{Kg} / \mathrm{m}^{3}\end{array}$ & $\begin{array}{c}\mathrm{Na}_{2} \mathrm{SiO}_{3} \\
\mathrm{Kg} / \mathrm{m}^{3}\end{array}$ & $\begin{array}{c}\mathrm{S.P} \\
\mathrm{Lit} / \mathrm{m}^{3}\end{array}$ \\
\hline M1 & 1 & 600 & 1120 & - & 650 & - & 44.1 & 110.2 & 13.36 \\
\hline M2 & 2 & 600 & 1120 & 65 & 585 & - & 44.1 & 110.2 & 13.36 \\
\hline M3 & 3 & 600 & 1120 & 130 & 520 & - & 44.1 & 110.2 & 13.36 \\
\hline M4 & 4 & 600 & 1120 & 195 & 455 & - & 44.1 & 110.2 & 13.36 \\
\hline M5 & 5 & 600 & 1120 & 260 & 390 & - & 44.1 & 110.2 & 13.36 \\
\hline M6 & 6 & 600 & 1120 & 325 & 325 & - & 44.1 & 110.2 & 13.36 \\
\hline M7 & A & 600 & 1120 & 128.7 & 514.8 & 6.5 & 44.1 & 110.2 & 13.36 \\
\hline M8 & B & 600 & 1120 & 127.4 & 509.6 & 13 & 44.1 & 110.2 & 13.36 \\
\hline M9 & C & 600 & 1120 & 126.1 & 504.4 & 19.5 & 44.1 & 110.2 & 13.36 \\
\hline
\end{tabular}

\section{Mixing and casting}

The following procedure was adopted for preparation of the mixes:
- Silica fume and GGBFS is mixed for 2 minutes in the mixer.
Published By:

Blue Eyes Intelligence Engineering and Sciences Publication

(C) Copyriaht: All rights reserved.

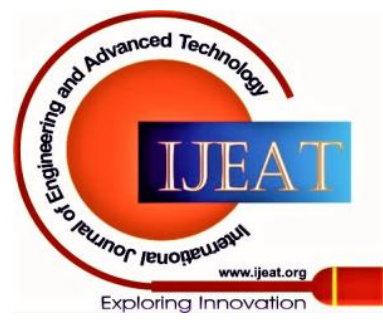


- Half of the activator is added in the mixer and rest of the alkali activator is mixed with super plasticizer.

- A bout half of the remaining activator is added to the paste in mixer and mixing together for 3 minutes.

- Sand and aggregate is added in the mixer with the remaining alkali activator and mixed for 3-4 minutes

- Cleaning the moulds and applying oil

- Fill the moulds with concrete in three layers each layer $5 \mathrm{~cm}$ and damping each layer 25 damp using damping rod.

- Samples then kept in rest period for 24 hoursafter that the samples demoulded and cured.

\section{E. Curing}

Geopolymer concrete samples which casted using normal activator demoulded after 24 hours and cured in room temperature. But geopolymer concrete samples in stage two which casted using hot activator were demoulded after 24 hours and half of samples were placed in room temperature till testing, it's the ambient temperature curing. And the other half of samples were cured in oven at temperature $75^{\circ} \mathrm{C}$ for 24 hours then kept in room temperature till testing to study the effect of using oven curing in case of hot activator. Nano silica samples (M7, M8 \&M9) cured only in oven at temperature $75^{\circ} \mathrm{C}$ for 24 hours then kept in room temperature till testing.

\section{A. Compressive strength}

\section{RESULTS AND ANSLYSIS}

In this study, GPC cubes of size 150x150x150mm were used to test the compressive strength at $7 \& 28$ days for both

Table -III: Results of compressive strength at ages 7\& 28 days using hot activator with different methods of curing

\begin{tabular}{|c|c|c|c|c|c|}
\hline $\begin{array}{l}\text { Mix } \\
\text { no. }\end{array}$ & $\begin{array}{l}\text { Type of } \\
\text { concrete }\end{array}$ & $\begin{array}{c}\text { Average } \\
\text { comp. strength } \\
\text { for oven cured } \\
\text { at } 7 \text { days }\end{array}$ & $\begin{array}{l}\text { Average comp. } \\
\text { strength for } \\
\text { ambient cured at } \\
7 \text { days }\end{array}$ & $\begin{array}{c}\text { Average comp. } \\
\text { strength for } \\
\text { oven cured at } 28 \\
\text { days }\end{array}$ & $\begin{array}{l}\text { Average comp. } \\
\text { strength for ambient } \\
\text { cured at } 28 \text { days }\end{array}$ \\
\hline M1 & 100\%GGBFS & 35 & 30 & 40 & 35 \\
\hline M2 & $\begin{array}{c}90 \% \text { GGBFS+10 } \\
\% \text { SF }\end{array}$ & 50 & 45 & 55.1 & 50 \\
\hline M3 & $\begin{array}{c}80 \% \text { GGBFS }+20 \\
\% \text { SF }\end{array}$ & 61.05 & 55.8 & 68.5 & 63.08 \\
\hline M4 & $\begin{array}{c}70 \% \text { GGBFS+30 } \\
\% \text { SF }\end{array}$ & 62.48 & 58.1 & 69.64 & 65 \\
\hline M5 & $\begin{array}{c}60 \% \text { GGBFS }+40 \\
\% \text { SF }\end{array}$ & 57.56 & 52.1 & 63 & 57.8 \\
\hline M6 & $\begin{array}{c}50 \% \text { GGBFS+50 } \\
\% \text { SF }\end{array}$ & 46.6 & 38 & 51.7 & 44 \\
\hline
\end{tabular}

normal activator temperature when samples cured in ambient temperature and hot activator temperature when mples cured in oven at temperature $75^{\circ} \mathrm{C}$ and in ambient fume is added in different ratios $(10,20,30,40 \% 50) \%$ partial replacement of GGBFS. The results at which samples failed are recorded in table III and IV.The maximum ilica 62.48MPa and 69.64MPa at age 7 and 28 days respectively when using hot activator and cured samples in oven. But when using hot activator and cured samples in ambient $65 \mathrm{MPa}$ at ages 7 and 28 days. So curing samples in oven at temperature $75^{\circ} \mathrm{C}$ shows improvement in compressive concrete as the addition of silica fume in concrete increases an to $30 \%$ the strength and durability of concrete increase fills the pores between aggregate and geopolymer cement and reduces the porosity of concrete. Also, silica fume with hydroxide ions (OH) which exists in the as a binder. So the internal transition zone "ITZ" enhanced by the physical and chemical effects of silica fume.

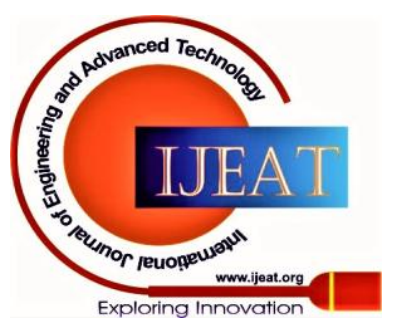


Development of High Strength Geopolymer Concrete using Nano Silica

Table-IV: Results of compressive strength using normal activator and curing samples in ambient temperature

\begin{tabular}{|c|c|c|c|}
\hline Mix No. & Type of concrete & $\begin{array}{c}\text { Average comp. } \\
\text { strength for ambient } \\
\text { cured at 7 days MPa }\end{array}$ & $\begin{array}{c}\text { Average comp. } \\
\text { strength for ambient } \\
\text { cured at 28 days MPa }\end{array}$ \\
\hline M1 & $100 \%$ GGBFS & 10 & 19.7 \\
\hline M2 & $90 \% G G B F S+10 \%$ SF & 15.4 & 35.62 \\
\hline M3 & $80 \% G G B F S+20 \%$ SF & 20 & 32.2 \\
\hline M4 & $70 \% G G B F S+30 \%$ SF & 23.24 & 25.5 \\
\hline M5 & $60 \% G G B F S+40 \%$ SF & 18 & \\
\hline M6 & $50 \% G G B F S+50 \% S F$ & 12.7 & \\
\hline
\end{tabular}

\section{B. Splitting tensile strength}

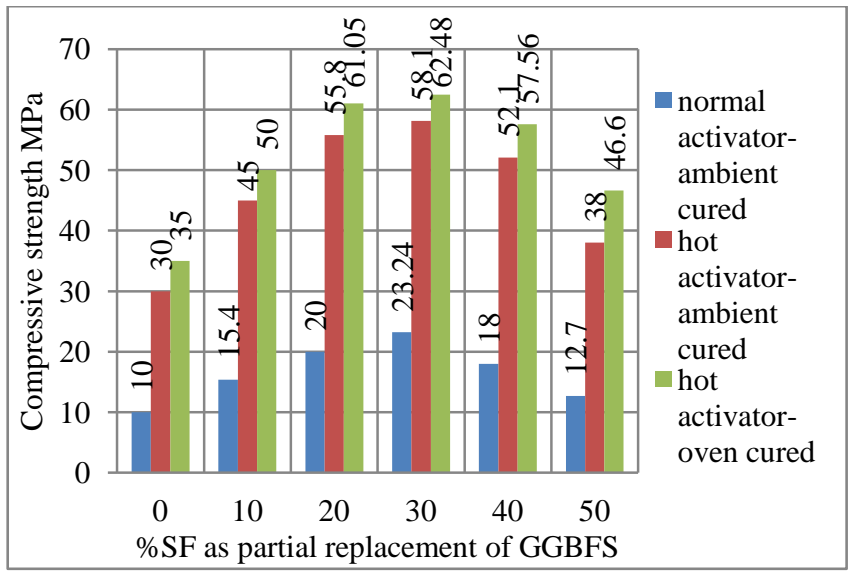

Fig.1: Comparison between the results of 7-days compressive strength.

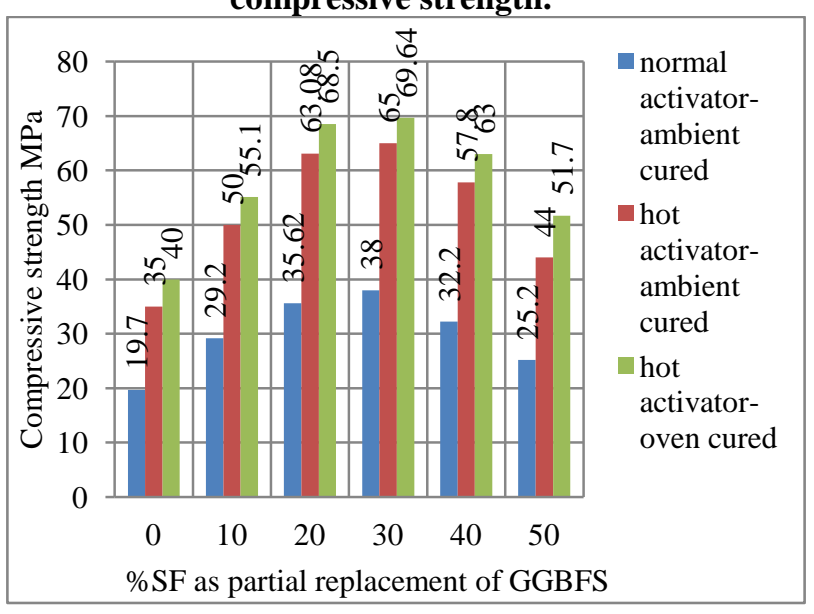

Fig. 2:Comparison between the results of 28-days compressive strength.
GPC cylinders of size $150 \mathrm{~mm}$ diameter and $300 \mathrm{~mm}$ height were used to test splitting tensile strength at 28 days. The load at which sample finally failed is recorded in tables $\mathrm{V}$ and VIfor both normal activator temperature when samples cured in ambient temperature and hot activator temperature when samples cured in oven at temperature $75^{\circ} \mathrm{C}$ and in ambient temperature. The maximum increase in splitting tensile strength is observed at 30\%replacement of silica fume. The splitting tensile strength is $7 \mathrm{MPa}$ when using hot activator and cured samples in oven. But when using hot activator and cured samples in ambient temperature the maximum splitting tensile strength is 6.3MPa. So curing samples in oven at temperature $75^{\circ} \mathrm{C}$ shows improvement in splitting tensile strength by $11 \%$. There is an increase in splitting tensile strength of concrete up to $30 \%$ of silica fume replacement because of the high pozzolanic nature of silica fume and its void filling ability.

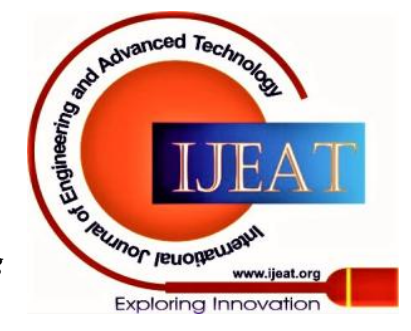


Table-V: Results of splitting tensile strength using hot activator

\begin{tabular}{|c|c|c|c|}
\hline Mix no. & Type of concrete & $\begin{array}{l}\text { Splitting strength } \\
\text { for oven curing } \\
\qquad \mathrm{MPa}\end{array}$ & $\begin{array}{l}\text { Splitting strength for } \\
\text { ambient temp. MPa }\end{array}$ \\
\hline M1 & 100\%GGBFS & 4 & 3.3 \\
\hline M2 & $90 \% G G B F S+10 \% S F$ & 5.3 & 4.7 \\
\hline M3 & $80 \% G G B F S+20 \% S F$ & 6.6 & 5.9 \\
\hline M4 & $70 \%$ GGBFS + 30\%SF & 7 & 6.3 \\
\hline M5 & $60 \%$ GGBFS + 40\%SF & 6.2 & 5.5 \\
\hline M6 & $50 \%$ GGBFS + 50\%SF & 4.6 & 3.9 \\
\hline
\end{tabular}

Table-VI: Results of splitting tensile strength using normal activator

\begin{tabular}{|c|c|c|}
\hline $\begin{array}{c}\text { mix. } \\
\text { no. }\end{array}$ & type of concrete & $\begin{array}{c}\text { Splitting strength for } \\
\text { ambient temperature } \\
\mathrm{MPa}\end{array}$ \\
\hline M1 & $100 \%$ GGBFS & 1.8 \\
\hline M2 & $90 \% G G B F S+10 \%$ SF & 2.7 \\
\hline M3 & $80 \% G G B F S+20 \%$ SF & 3.4 \\
\hline M4 & $70 \% G G B F S+30 \%$ SF & 3.7 \\
\hline M5 & $60 \% G G B F S+40 \% S F$ & 3.1 \\
\hline M6 & $50 \% G G B F S+50 \% S F$ & 2.3 \\
\hline
\end{tabular}

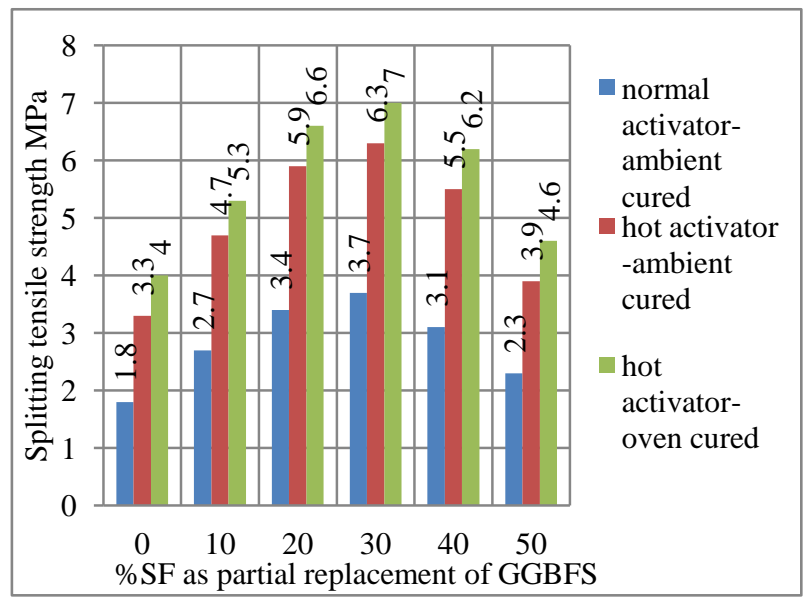

Fig. 3: Comparison between the results of splitting tensile strength.

\section{Modulus of Elasticity}

GPC cylinders of size $150 \mathrm{~mm}$ diameter and $300 \mathrm{~mm}$ height were used to test modulus of elasticity at 28 days. The load at which sample finally failed is recorded in tables VII and VIIIfor both normal activator temperature when samples cured in ambient temperature and hot activator temperature when samples cured in oven at temperature $75^{\circ} \mathrm{C}$ and in ambient temperature. The maximum increase in modulus of elasticity is observed at $30 \%$ replacement of silica fume. The maximummodulus of elasticity is $32612.5 \mathrm{MPa}$ when using hot activator and cured samples in oven. But when using hot activator and cured samples in ambient temperature the maximummodulus of elasticity is 29875.5. So curing samples in oven at temperature $75^{\circ} \mathrm{C}$ shows improvement in modulus of elasticity by $9.2 \%$.

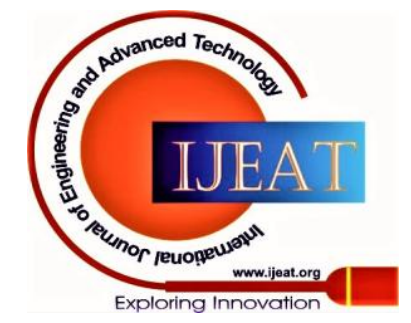


Development of High Strength Geopolymer Concrete using Nano Silica

Table-VII: Results of modulus of elasticity using hot activator

\begin{tabular}{|c|c|c|c|}
\hline Mix no & type of concrete & $\begin{array}{l}\text { Young's modulus for } \\
\text { oven cured samples } \\
\mathrm{MPa}\end{array}$ & $\begin{array}{l}\text { Young's modulus for ambient } \\
\text { temperature cured samples } \\
\text { MPa }\end{array}$ \\
\hline M1 & 100\%GGBFS & 23534.8 & 19426.4 \\
\hline M2 & $90 \%$ GGBFS + 10\%SF & 28036.36 & 24542.7 \\
\hline M3 & $80 \%$ GGBFS + 20\%SF & 31137.5 & 28148.98 \\
\hline M4 & 70\%GGBFS + 30\%SF & 32612.5 & 29875.5 \\
\hline M5 & $60 \%$ GGBFS + 40\%SF & 30430.5 & 27028.18 \\
\hline M6 & $50 \%$ GGBFS + 50\%SF & 25500 & 21905.5 \\
\hline
\end{tabular}

Table-VIII: Results of modulus of elasticity using normal activator

\begin{tabular}{|c|c|c|}
\hline \multicolumn{3}{|c|}{ activator } \\
\hline $\begin{array}{l}\text { Mix. } \\
\text { No. }\end{array}$ & type of concrete & $\begin{array}{l}\text { Young's modulus for } \\
\text { ambient temperature } \\
\text { cured samples MPa }\end{array}$ \\
\hline M1 & 100\%GGBFS & 11235.84 \\
\hline M2 & $90 \%$ GGBFS + 10\%SF & 13989.3 \\
\hline M3 & $80 \% G G B F S+20 \% S F$ & 16607.9 \\
\hline M4 & $70 \% G G B F S+30 \% S F$ & 18224.05 \\
\hline M5 & $60 \%$ GGBFS + 40\%SF & 15866.5 \\
\hline M6 & $50 \% G G B F S+50 \% S F$ & 12486.13 \\
\hline
\end{tabular}

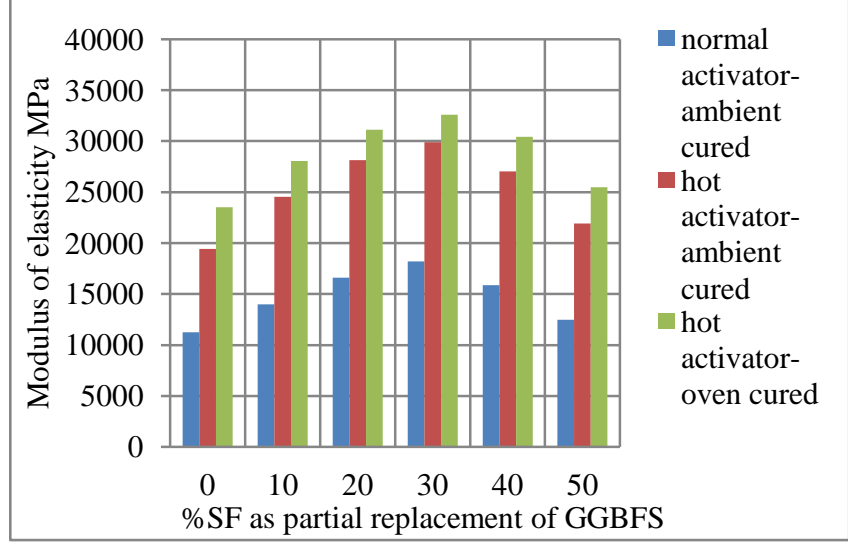

Fig. 4: Comparison between the results of modulus of elasticity

\section{Nano silica}

The optimum sample which consists of (70\%GGBFS+30\%SF) developed by adding nano silica with ratios 1,2 and $3 \%$ and the results of compressive strength at ages 7 and 28 days, splitting tensile strength and modulus of elasticity showed in table-IX.

Table-IX: Results of compressive strength at ages 7 and 28 days, splitting tensile strength and modulus of elasticity with different nano silica content

\begin{tabular}{|c|c|c|c|c|c|}
\hline Mix no. & \%NS & $\begin{array}{c}\text { comp. strength at 7 } \\
\text { daysMPa }\end{array}$ & $\begin{array}{c}\text { comp. strength at } \\
28 \text { days MPa }\end{array}$ & $\begin{array}{c}\text { splitting tensile } \\
\text { strength MPa }\end{array}$ & MPa \\
\hline M7 & 1 & 66.2 & 71.77 & 7.5 & 33998.6 \\
\hline M8 & 2 & 75.11 & 86.71 & 8.85 & 35981.18 \\
\hline M9 & 3 & 45.6 & 55.03 & 6.4 & 30572.21 \\
\hline
\end{tabular}

The results showed that up to $2 \%$ nano silica gives higher results in compressive strength, splitting tensile strength and modulus of elasticity but after that the results decreases according to agglomerate effect. This is due to addition of nano silica increases strength and durability of concrete more than micro silica because of its smaller size than micro silica. Also its high surface area make it reacts faster and forms extra gel which acts as binder between aggregate and cement grains. Although the increase of nano silica

above certain rate (2\%) gives negative effect because of agglomerate effect as the high energy that emits in the hydration process make cement grains congregate together that causes more pores in concrete so that it decreases its mechanical properties and durability.

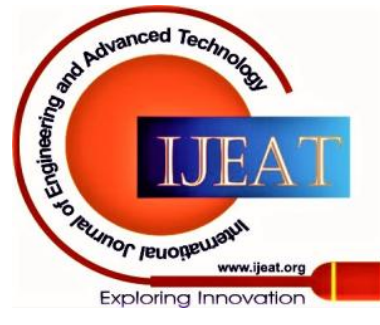




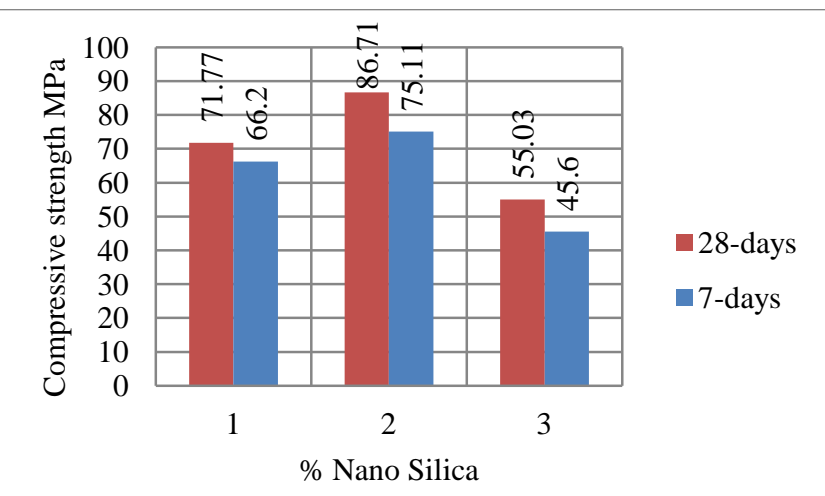

Fig. 5: Results of compressive strength at age 7 and 28 days when adding nano silica

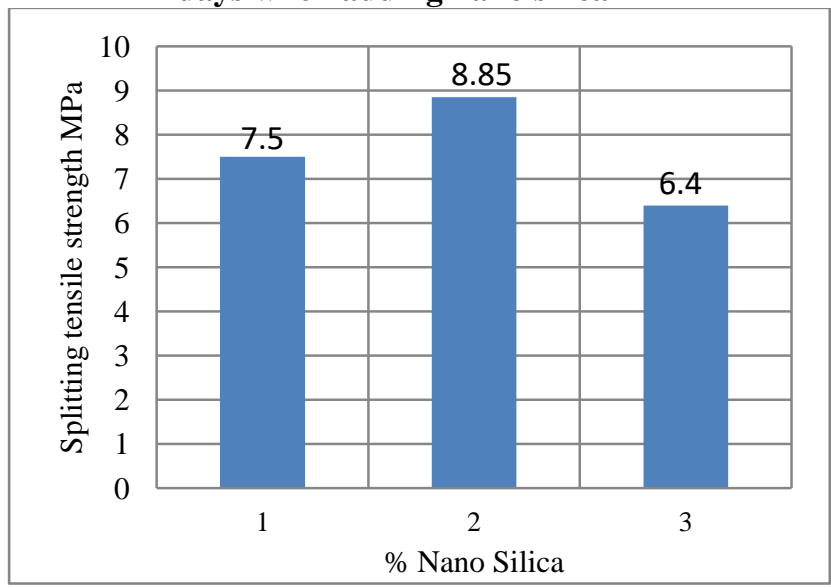

Fig. 6: Results of splitting tensile strength when adding nano silica

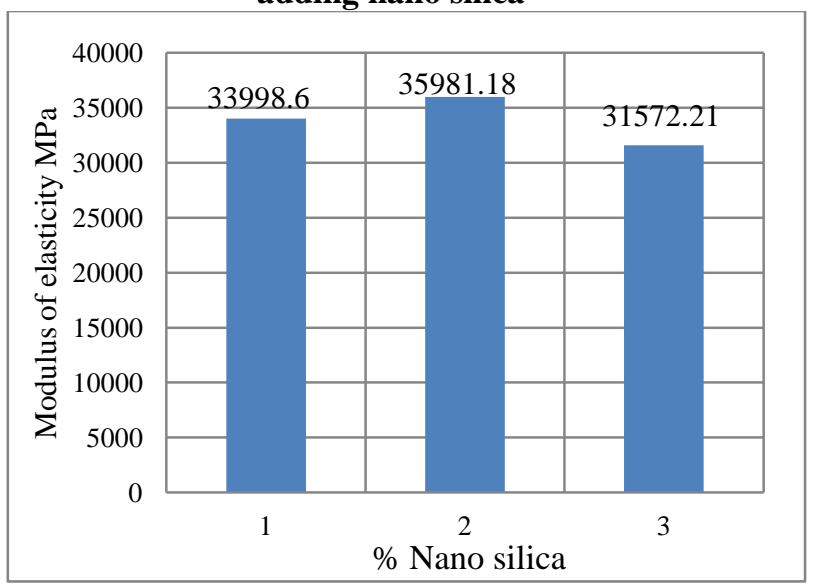

Fig.7: Results of modulus of elasticity when adding nano silica

\section{E. Stress strain curves}

Stress - strain curves is plotted for samples casted by hot activators temperature only (samples cured in ambient temperature and at oven without nano silica and samples cured at oven with adding nano silica). Stress-strain curves showed that, the mixture which containing $2 \%$ nano silica gives higher stresses so it is stiffer than the other mixtures. This is due to addition of nano silica increases strength and durability of concrete more than micro silica because of its smaller size than micro silica. Also its high surface area make it reacts faster and forms extra gel which acts as binder between aggregate and cement grains. Also, for samples which casted without nano silica it was found that samples which cured in oven give maximum stresses than samples cured in ambient temperature. So curing samples in oven makes it stiffer. The maximum increase in stressfor samples without nano silicawas observed at 30\% replacement of silica fume.

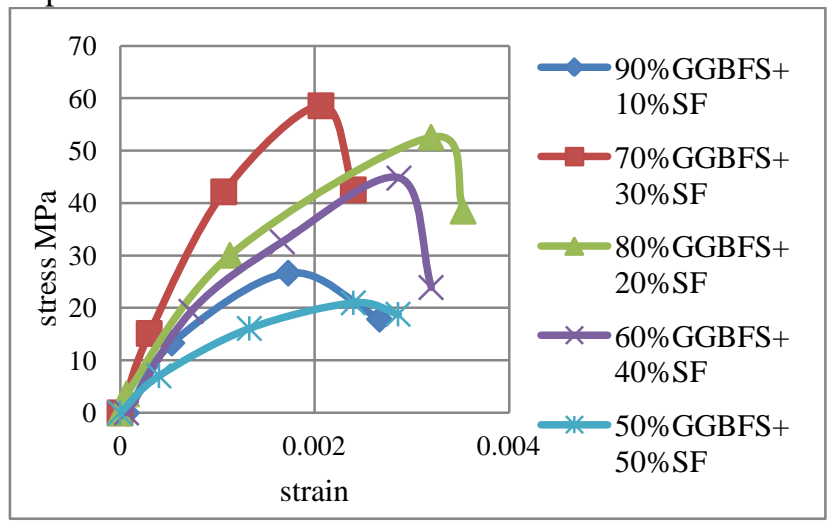

Fig.8: Stress-Strain curves for geopolymer concrete mixes cured in oven at temperature $75^{\circ} \mathrm{c}$.

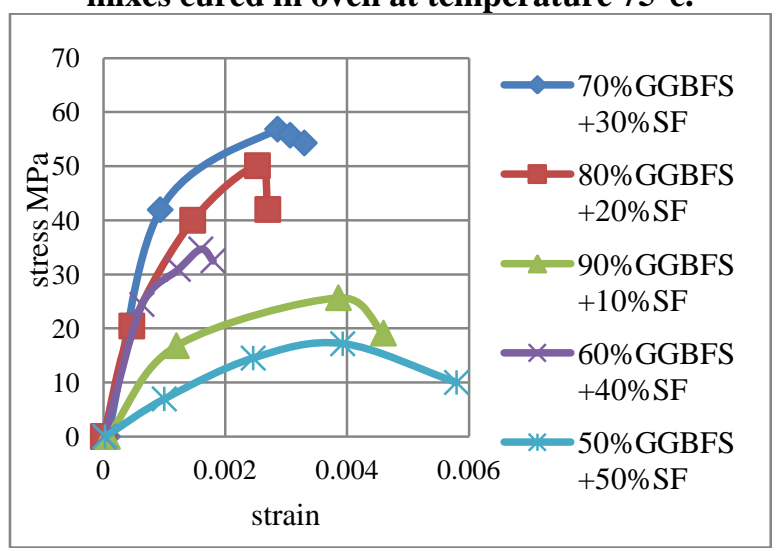

Fig.9: Stress-Strain curves for geopolymer concrete mixes cured in ambient temperature.

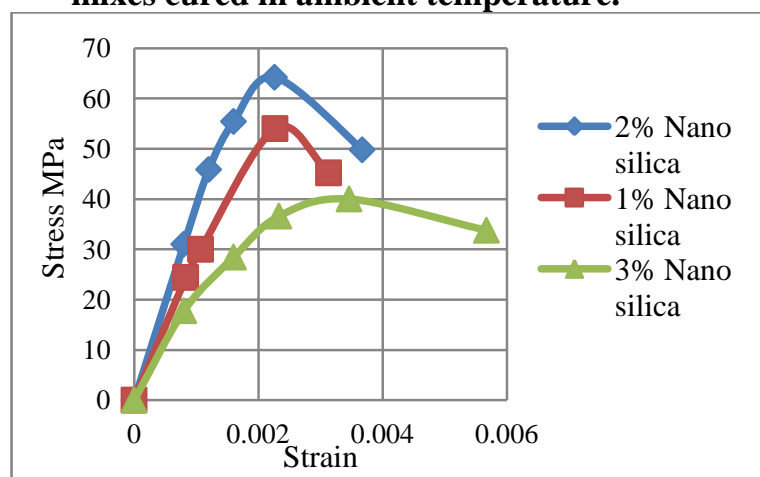

Fig. 10: Stress-Strain curve for nano silica mixes.

\section{CONCLUSIONS}

This paper presents the development of high strength geopolymer concrete. The binder used in this study is SF \& GGBFS in different ratios. Control trial mix "M1" is the mixture without silica fume. Samples casted by different temperature activator and cured by different methods "oven curing at $75^{\circ} \mathrm{c} \&$ ambient temperature curing" then tested for mechanical properties. Optimum sample defined with its method of curing and developed by adding nano silica in different ratios (1, 2 \&3)\% of the total weight of cementitious materials. The results showed that:-

Published By:

Blue Eyes Intelligence Engineering and Sciences Publication

(C) Copyright: All rights reserved.

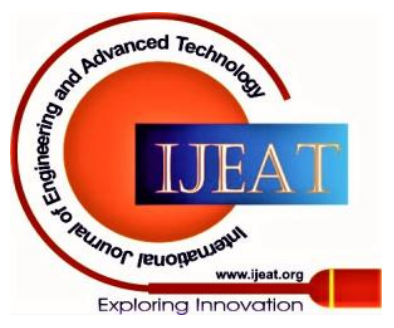




\section{Development of High Strength Geopolymer Concrete using Nano Silica}

1. The results showed that for different activators temperature and for different methods of curing the mixture which reached high compressive strength, splitting tensile strength and modulus of elasticity was observed at $30 \%$ replacement.

2. Using hot activator temperature gives higher results than using normal activators temperature.

3. In case of using hot activator, curing samples in oven at temperature $75^{\circ} \mathrm{C}$ is more efficient than curing samples in ambient temperature.

4. Adding nano silica to the optimum geopolymer concrete sample up to $2 \%$ increasing the results but after this ratio the results decreases.

5. The results of compressive strength approximately increased by $75 \%$ as average at age 28 days when using hot activator.

6. The results of splitting tensile strength and modulus of elasticity approximately increased by $72 \%$ when using hot activator.

7. In compressive strength the percentage of increase ranges between (7.5 to 22$) \%$ at 7 days from ambient to oven curing and ranges between (7.1 to 17.5$) \%$ at 28 days.

8. In compressive strength the results increased from 7 to 28 days by ratios from 9.4 to $14.3 \%$ for oven curing and from 10.9 to $16.67 \%$ for ambient temperature curing.

9. In splitting tensile strength when using hot activator the percentage of increase ranges between (11 to 21)\% from ambient to oven curing.

10. In modulus of elasticity when using hot activator the percentage of increase ranges between (9.16 to 21.1 )\% from ambient to oven curing.

\section{REFERANCES}

1. Kumaravel S. and Girija K. U. (2014), Development of HighStrength Geopolymer concrete, Journal of Construction Engineering Technology and Management, Vol. 4, pp. 8-13

2. Rangan B. V. (2014), Geopolymer concrete for environmental protection, The Indian concrete journal, Vol. 88, pp.41-48, 50-59.

3. Deb P. S., Nath P. and Sarker P. K. (2013), Durability of Fly Ash Based Geopolymer Concrete, thesis presented for the Degree of Master of Philosophy (Civil Engineering) of Curtin University.

4. Nurruddin M. F., Mohammed B. S., Haruna S. and Shaaban I. G. (2018), Methods of curing geopolymer concrete: A review, International journal of advanced and applied sciences, Vol. 5, pp. 3136.

5. Maheswaran S., Bhuvaneshwari B., Palani G.S., Nagesh R. I. andKalaiselvam S. (2012), An Overview on the Influence of Nano Silica in Concrete and a Research Initiative, Research Journal of Recent Sciences,Vol. 2, pp. 17-24.

6. Jindal B. B., Yadav A. , Anand A. and Badal A. (2016), Development of high strength fly ash based Geopolymer concrete with Alccofine, Journal of Mechanical and Civil engineering, Vol. 16, pp. 55-58.

7. Ambily P. S. , Gunasekaran U., Dattatreya J. K. and Iyar N. R.(2014), Development of ultra high performance geopolymer concrete, Magazine of concrete research institution of civil engineering, Vol. 66, pp. 82-89.

8. Singh L., Kumar A. and Singh A. (2016), STUDY OF PARTIAL REPLACEMENT OF CEMENT BY SILICA FUME, International journal of advanced research, Vol. 4, pp. 104-120

9. Rahul K. and Andavan S. (2017), Experimental study on partial replacement of cement with nano silica in the concrete, International journal of trend in scientific research and development (IJTSRD), Vol. 2, pp. 797-803.

10. AbdelBaky S., Yehia S. and Khalil I. S. (2013), Infulence of nano silica addition on properties of fresh and hardened cement mortar, Housing \& Building National Research Centre, Cairo, Egypt Shorouk Academy, Cairo, Egypt.
11. Kumar A. and Singh G. (2018), Effect of Nano Silica on the Fresh and Hardened Properties of Cement Mortar, International Journal of Applied Engineering Research, Vol.1 13, pp. 11183-11188.

\section{AUTHORS PROFILE}

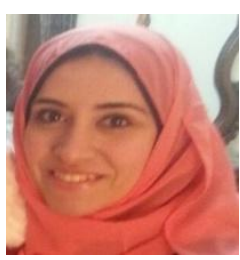

Nancy T. Hussien Graduated from faculty of engineering ,Matteriya, Helwan University, Civi engineering department in 2014. sheworked as teaching assistant at Cairo higher institute, Cairo, Egypt from 2014 to 2015 then worked as teaching assistant at Egyptian Russian University (ERU) faculty of engineering from 2015 till now in Badr city cairo, Egypt.

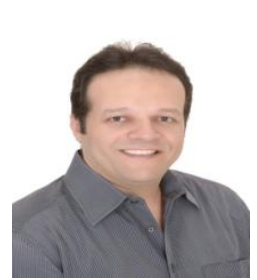

Ahmed M. Ahmed is an assistant professor at the civil engineering department, faculty of engineering at Mataria, Helwan University. He is currently an acting assistant professor at Nile University, Egypt. Dr. Ahmed has aPh.D. degree in structural engineering from the University of Alabama at Birmingham (USA) in 2016. He is specialized in the properties and strength of materials. Dr. Ahmed is active in research and academic supervision on numerous engineering post-graduate students in the field of material science and structural engineering.

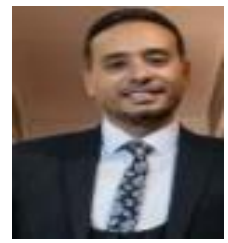

Dr. Mohamed H. Agamy is an Associate professor in Civil Engineering Department, Faculty of Engineering at Mataria, Helwan University, Cairo, Egypt. He has received his Ph.D. degree from Helwan University, Cairo, Egypt in 2015. He is specialized in Structure Analysis and modeling. Dr. Helmy is active in research and academic supervision on numerous engineering post-graduate students in the field of structure science.

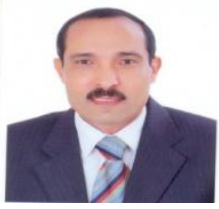

Dr. Gouda M. Ghanem

- $\quad$ 1982: B.Sc. In Civil Engineering, Cairo Univ., Egypt.

1987: M.Sc. In Structural Engineering Cairo Univ., Egypt.

1992: Ph.D. In Structural Engineering,

Channel Program Between Helwan University, Egypt and Drexel University, USA.

- 1982-1992: Demonstrator \& Assistant Lecturer , Structural Engineering, Faculty of Engineering at Mataria, Helwan University, Cairo, Egypt

- 1992-1998: Assistant Prof of Structural Engineering, Faculty of Engineering at Mataria, Helwan University, Cairo, Egypt.

- 1933- Till Now : A Board of director member's in the center of planning and architectural design ( CPAS).

- 2003-Now : Prof. of Properties and Strength of Materials, Faculty of Engineering at Mataria, Helwan University, Cairo, Egypt.

- 2005-2009: Director of Research Center of Technological Development (RCTD), Helwan Univ., Cairo, Egypt.

- 2010-2012 :Vice Dean Of The Higher Institute Of Engineering ElShrouk Academy.

- 2012-2018 : Dean Of The Higher Institute Of Engineering - El-Shrouk Academy.

- 2018-Now : Vice Presedent of El-Shrouk Academy.

- Encouragement Country Award for the year of 2001 in Structural Engineering Awarded by Academy of Scientific Research \& Technology - Ministry of High Education, Egypt.

- Helwan University Award for the Best Research in Structura Engineering for the year of 2003.

- Supervising twenty six Ph.D. Candidates andThirty eight M. Sc Candidates.

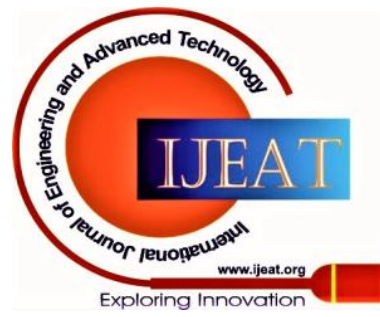

